\title{
PELATIHAN BIDANG AKUNTANSI SEKTOR PUBLIK KEPADA GURU SMK JURUSAN AKUNTANSI DI KAB. LUMAJANG
}

\author{
Imam Mulyono ${ }^{1}$, Kartika Dewi $\mathrm{SS}^{2}, \mathrm{R} \mathrm{Setiawan}^{3}$, Sumiadji $^{4}$, Padma Andriana $^{5}$ \\ 1,2,3,4,5 Jurusan Akuntansi, Politeknik Negeri Malang \\ ${ }^{1}$ imam.mulyono@polinema.ac.id, ${ }^{2}$ kartika.dewi@ polinema.ac.id, ${ }^{3}$ rsetiawan@ polinema.ac.id, \\ ${ }^{4}$ sumiadji@polinema.ac.id, ${ }^{5}$ padma.andriana@polinema.ac.id
}

\begin{abstract}
Abstrak - Materi Akuntansi Sektor Publik (ASP) mulai dikenalkan dan menjadi mata pelajaran wajib pada muatan kurikulum nasional di Jurusan Akuntansi pada level SMK di Tahun 2017. Dampaknya guru harus mencari bentuk pembelajaran ASP yang sesuai dengan daya serap murid SMK, karena karakter ASP sangat berbeda dengan akuntansi sektor privat, dan guru akuntansi di tingkat SMK belum mengenal materi pelajaran ASP, selain itu area ASP yang sangat luas, karena terdiri dari Akuntansi Organisasi Nirlaba dan Akuntansi Pemerintahan (Akuntansi Pemerintah Pusat, Akuntansi Pemerintah Daerah, Akuntansi BLU/BLUD, dan Akunatnsi untuk Desa). Tujuan kegiatan PKM ini, untuk menguatkan pemahaman dan memperkaya referensi ASP terhadap Guru SMK, sehingga dapat mengevaluasi kurikulum mata pelajaran ASP. Tim pemateri dari dosen- Jurusan Akuntansi Politeknik Negeri Malang, dan pesertanya adalah Guru SMK yang tergabung dalam MGMP Akuntansi SMK di Kabupaten Lumajang. Metode pelatihan yang digunakan: (1) Ceramah, (2) Diskusi dan Tanya jawab, dan (3) Praktek Proses Akuntansi Keuangan Daerah. Kegiatan PkM dilaksanakan tanggal 12-15 September 2019 (32 Jam Pel), bertempat di SMKN 1 Lumajang, diikuti 31 Peserta. Hasil dari kegiatan PkM adalah: (1) Peserta mendapatkan materi yang ter-update Akuntansi Sektor Publik, dan (2) Peserta mampu mengevaluasi kurikulum mata pelajaran ASP sehingga menghasilkan usulan kurikulum mata pelajaran ASP yang baru.
\end{abstract}

Kata kunci: Akuntansi Sektor Publik, Akuntansi Pemerintahan, SMK.

\section{PENDAHULUAN}

\subsection{Latar Belakang}

Materi Akuntansi Sektor Publik (ASP) mulai dikenalkan dan menjadi mata pelajaran wajib pada muatan kurikulum nasional di Jurusan Akuntansi pada level SMK di Tahun 2017. Dampaknya guru harus mencari bentuk pembelajaran ASP yang sesuai dengan daya serap murid SMK, karena karakter ASP sangat berbeda dengan akuntansi sektor privat, dan guru akuntansi di tingkat SMK belum mengenal materi pelajaran ASP, selain itu area ASP yang sangat luas, karena terdiri dari Akuntansi Organisasi Nirlaba dan Akuntansi Pemerintahan (Akuntansi Pemerintah Pusat, Akuntansi Pemerintah Daerah, Akuntansi BLU/BLUD, dan Akunatnsi untuk Desa). Berdasarkan pada analisis situasi tersebut dan mengingat pentingnya pelatihan dan pembinaan atas para guru SMK di Jurusan Akuntansi, maka perlu diberikan pelatihan-pelatihan Bidang Akuntansi Sektor Publik kepada para guru SMK di Jurusan Akuntansi di Kabupaten Lumajang. Tujuan kegiatan PKM ini, untuk menguatkan pemahaman dan memperkaya referensi ASP terhadap Guru SMK, sehingga dapat mengevaluasi kurikulum mata pelajaran ASP.

\section{TINJAUAN PUSTAKA}

Akuntansi sektor publik telah mengalami perkembangan sangat pesat, saat ini terdapat perhatian yang lebih besar terhadap penilaian kelayakan praktik manajemen pemerintahan yang mencakup sistem akuntansi keuangan, sistem akuntansi manajemen, perencanaan keuangan serta berbagai implikasi finansial atas kebijakan yang dilakukan pemerintah. Sektor publik saat ini tidak hanya di institusi pemerintahan saja akan tetapi partai politik, ta'mir masjid, sekolah, rumah sakit, lembaga pendidikan dan yayasan juga merupakan sektor publik. Organisasi tersebut dikatakan sebagai sektor publik karena menyediakan jasa layanan terhadap publik.

Organisasi sektor publik merupakan sebuah entitas ekonomi yang berbeda dengan organisasi profit. Sektor publik memiliki sumber daya ekonomi yang besar. Organisasi sektor publik memiliki perbedaan dengan organisasi laba/komersil dimana tujuan dari sumber daya ekonomi yang dikelola tidak untuk mencari laba (nirlaba). Istilah "Sektor Publik" memiliki pengertian yang bermacam-macam. Hal tersebut merupakan konsekuensi dari luasnya wilayah publik, sehingga setiap disiplin ilmu memiliki cara pandang dan definisi yang berbeda. Dari sudut pandang ilmu ekonomi, sektor publik dapat dipahami sebagai suatu entitas yang aktivitasnya berhubungan dengan usaha untuk menghasilkan barang dan pelayanan publik dalam rangka memenuhi kebutuhan dan hak publik. (Mardiasmo, 2009:2)

Organisasi sektor publik bergerak dalam lingkungan yang kompleks dan turbulance. Komponen lingkungan yang mempengaruhi organisasi sektor publik meliputi faktor ekonomi, politik, kultur, dan demografi. Organisasi sektor publik atau organisasi yang tidak bertujuan mencari keuntungan memiliki ciri - ciri sebagai berikut: (a) Organisasi sektor publik tidak mempunyai motif mencari laba atau mencari keuntungan bukanlah tujuan utama bagi organisasi jenis ini. (b) Organisasi sektor publik dimiliki secara kolektif, artinya adalah hak kepemilikan tidak ditujukan oleh saham yang dapat dimiliki secara perseorangan yang dapat di perjual belikan, dan (c) Pihak - pihak yang memberikan sumber keuangan kepada organisasi non-profit ini, tidak harus menerima imbalan secara langsung, baik berupa barang, uang, 
atau jasa. (Sabeni, 1996:2)

Menurut Mardiasmo (2009:13) akuntansi sektor publik dengan akuntansi komersial memiliki beberapa persamaan, antara lain: (a) Akuntansi sektor publik maupun akuntansi komersial sama - sama memberikan informasi mengenai posisi keuangan dan hasil operasi. (b) Akuntansi sektor publik maupun akuntansi sektor komersil mengikuti prinsip - prinsip dan standar akuntansi yang diterima umum, seperti: (a) Prinsip Objektivitas (Objectivity), (b) Prinsip Konsistensi (Consistency), (c) Prinsip Materialitas (Materiality), (d) Prinsip Pengungkapan Penuh yang memadai (Full Disclousure), (e) Proses pengendalian manajemen, termasuk manajemen keuangan, pada dasarnya sama di kedua sektor. Kedua sektor sama - sama melaksanakan fungsi manajemen, yaitu; perencanaan, pengorganisasian, dan pengendalian, (f) Pada beberapa hal, kedua sektor menghasilkan produk yang sama, misalnya baik pemerintah maupun swasta sama - sama bergerak di bidang transportasi massa, kesehatan, dan sebagainya.

Di samping beberapa persamaan di atas juga dapat diidentifikasi beberapa perbedaan antara akuntansi sektor publik dengan akuntansi komersial, secara lebih rinci, perbedaan sifat dan karakteristik sektor publik dengan sektor swasta dapat dilihat dengan membandingkan beberapa hal, yaitu:

1. Tujuan organisasi,

2. Sumber pembiyaan,

3. Pola pertanggungjawaban,

4. Struktur organisasi,

5. Karakteristik anggaran,

6. Stakeholder yang dipengaruhi, dan

7. Sistem akuntansi yang digunakan

Tabel 1. Perbedaan Sifat dan Karakteristik Org. Sektor Publik dengan Swasta

\begin{tabular}{|l|l|l|}
\hline Perbedaan & Sektor Publik & Sektor Swasta \\
\hline $\begin{array}{l}\text { Tujuan } \\
\text { organisasi }\end{array}$ & $\begin{array}{l}\text { Nonprofit } \\
\text { motive }\end{array}$ & Profit motive \\
\hline $\begin{array}{l}\text { Sumber } \\
\text { pendanaan }\end{array}$ & $\begin{array}{l}\text { Pajak, retribusi, } \\
\text { utang, obligsi } \\
\text { pemerintah, } \\
\text { laba, } \\
\text { BUMN/BUMD, } \\
\text { penjualan aset } \\
\text { negara, dsb }\end{array}$ & $\begin{array}{l}\text { Pembiayaan } \\
\text { sendiri, laba } \\
\text { ditahan, } \\
\text { penjualan } \\
\text { aktiva } \\
\text { Pembiayaan } \\
\text { eksternal: } \\
\text { utang bank, } \\
\text { obligasi, } \\
\text { penerbitan } \\
\text { saham }\end{array}$ \\
\hline $\begin{array}{l}\text { Pertanggungja } \\
\text { waban }\end{array}$ & $\begin{array}{l}\text { Pertanggungjaw } \\
\text { aban kepada } \\
\text { masyarakat } \\
\text { (publik) dan } \\
\text { parlemen } \\
\text { (DPR/DPRD) }\end{array}$ & $\begin{array}{l}\text { Pertanggungja } \\
\text { waban kepada } \\
\text { pemegang } \\
\text { saham dan } \\
\text { kreditor }\end{array}$ \\
\hline $\begin{array}{l}\text { Birokratis, kaku, } \\
\text { dan hierarkis } \\
\text { organisasi }\end{array}$ & $\begin{array}{l}\text { Fleksibel: } \\
\text { datar, piramid, } \\
\text { lintas }\end{array}$ \\
\hline
\end{tabular}

\begin{tabular}{|l|l|l|}
\hline & & $\begin{array}{l}\text { fungsional, } \\
\text { dsb. }\end{array}$ \\
\hline $\begin{array}{l}\text { Karakteristik } \\
\text { anggaran }\end{array}$ & $\begin{array}{l}\text { Terbuka untuk } \\
\text { publik }\end{array}$ & $\begin{array}{l}\text { Tertutup untuk } \\
\text { publik }\end{array}$ \\
\hline
\end{tabular}

Sumber: Mardiasmo (2009:8)

Tabel 2. Perbedaan Stakeholder Sektor Publik dengan Sektor Swasta

\begin{tabular}{|c|c|}
\hline $\begin{array}{c}\text { Stakeholder sektor } \\
\text { publik }\end{array}$ & $\begin{array}{c}\text { Stakeholder sektor } \\
\text { swasta }\end{array}$ \\
\hline $\begin{array}{l}\text { Stakeholder Eksternal } \\
\text { 1. Masyarakat pengguna } \\
\text { jasa publik } \\
\text { 2. Perusahaan dan } \\
\text { organisasi sosial ekonomi } \\
\text { yang menggunakan } \\
\text { pelayanan publik sebagai } \\
\text { input atas aktivitas } \\
\text { organisasi } \\
\text { 3. Bank sebagai kreditor } \\
\text { pemerintah } \\
\text { 4. Badan-badan } \\
\text { internasional, seperti Bank } \\
\text { Dunia, IMF, ADB, PBB, } \\
\text { dsb. } \\
\text { 5. Investor asing dan } \\
\text { country analyst } \\
6 \text {. Generasi yang akan } \\
\text { dating }\end{array}$ & $\begin{array}{l}\text { Stakeholder Eksternal } \\
\text { 1. Bank sebagai kreditor } \\
\text { 2. Serikat buruh } \\
\text { 3. Pemerintah } \\
\text { 4. Pemasok } \\
\text { 5. Distributor } \\
\text { 6. Pelanggan } \\
\text { 7. Masyarakat } \\
\text { 8. Serikat dagang (trade } \\
\text { union) } \\
\text { 9. Pasar Modal }\end{array}$ \\
\hline $\begin{array}{l}\frac{3}{\text { Stakeholder } \text { Internal }} \\
\text { 1. Lembaga negara } \\
\text { (misalnya: kabinet, MPR, } \\
\text { DPR/DPRD, dsb) } \\
\text { 2. Kelompok politik } \\
\text { (partai politik) } \\
\text { 3. Manajer publik } \\
\text { (gubernur, bupati, direktur } \\
\text { BUMN/BUMD) } \\
\text { 4.Pegawai pemerintah }\end{array}$ & $\begin{array}{l}\text { Stakeholder Internal } \\
\text { 1. Manajemen } \\
\text { 2. Karyawan } \\
\text { 3. Pemegang saham }\end{array}$ \\
\hline
\end{tabular}

Sumber: Mardiasmo (2009:12)

Organisasi-organisasi sektor publik sering kita jumpai dalam kehidupan kita, dalam kehidupan seharihari, kita berurusan dengan instansi pemerintah. Jika dilihat secara garis besar, jenis-jenis organisasi sector publik diatas dapat dibagi menjadi dua, yaitu; (1) Instansi Pemerintah, merupakan bagian organisasi sector publik yang berbentuk instansi pemerintah, antara lain: (a) Pemerintah Pusat (Kementrian, Lembaga dan Badan Negara), (b) Pemerintah Daerah (SKPD/OPD), (c) Akuntansi BLU/BLUD; (2) Organisasi Nirlaba, merupakan bagian organisasi sektor public yang dimiliki dan dikelola oleh sekumpulan orang/kelompok (Yayasan, Partai Politik, dan lain-lain).

Mengacu pada jenis-jenis organisasi sektor public, sehingga bentuk laporan keuangannya mempunyai karakter sendiri dan berbeda dengan laporan keuangan sector privat. Berikut ini, merupakan standar akuntansi untuk organisasi sektor public: 


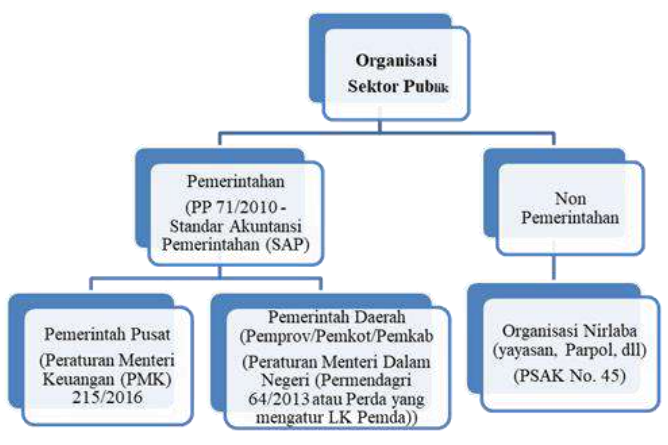

Gambar 1. Ruang Lingkup Organisasi Nirlaba

\section{SOLUSI DAN TARGET LUARAN}

Kegiatan PKM in untuk memperkaya referensi terhadap Guru SMK Jurusan Akuntansi tentang ASP dan memberikan solusi untuk menyesuaikan bahan ajar yang terkait dengan materi ASP, serta memberikan pilihan bagi Guru-Guru untuk menentukan lingkup ASP yang akan diberikan kepada siswa karena lingkup ASP yang sangat luas, yang terdiri dari Akuntansi Pemerintahan (Pemerintahan Pusat, Pemerintahan Daerah, BLU/BLUD, dan Pemerintahan Desa) dan Akuntansi Organisasi Nirlaba. Luaran Kegiatan yang dihasilkan: (1) Peningkatan daya saing bagi guru dan murid karena mempunyai kompetensi tambahan bidang ASP. (2) Guru-guru mampu mengevaluasi kurikulum ASP untuk siswa SMK, sehingga menghasilkan kurikulum mata pelajaran ASP utamanya bidang Akuntansi Keuangan Daerah yang sesuai dengan PP No. 71/2010 \& Permendagri 64/2013.

\section{METODE PELAKSANAAN}

Kegiatan $\mathrm{PkM}$ ini, tim penyaji/pemateri dari dosen-dosen Jurusan Akuntansi Politeknik Negeri Malang, dan Peserta kegiatan PKM ini adalah para Guru SMK Jurusan Akuntansi yang tergabung dalam MGMP Akuntansi SMK di Kabupaten Lumajang. Metode yang digunakan dalam pengabdian kepada masyarakat ini adalah: (1) Ceramah, (2) Diskusi dan Tanya jawab, (3) Praktek Proses Akuntansi di Organisasi Sektor Publik (Penjurnalan, Posting, \& Penyusunan Laporan Keuangan). Dalam rangka evaluasi atas keberhasilan pelatihan, akan dilakukan pre-test dan post test sebagai indikator keberhasilan pelaksanaan kegiatan.

\section{HASIL DAN CAPAIAN LUARAN}

Pelaksanaan kegiatan PkM ini, diikuti 31 Guru SMK bidang Akuntansi yang tergabung dalam MGMP Akuntansi SMK di Kabupaten Lumajang (terlampir), bertempat di Ruang Multimedia SMKN 1 Lumajang. Sarana yang dipakai, antara lain Whiteboard, LCD, Modul ASP, dan Alat Tulis Kantor. Kegiatan PkM ini dilaksanakan selama 4 hari, mulai tanggal 12-15 September 2019, dengan materi sebagai berikut:

\begin{tabular}{|l|ll|l|}
\hline No. & Materi Pelatihan & Jumlah Jam \\
\hline 1 & $\begin{array}{l}\text { Karakteristik Organisasi \& } \\
\text { Lingkungan Sektor Publik }\end{array}$ & 4 Jam \\
\hline
\end{tabular}

\begin{tabular}{|l|l|l|}
\hline 2 & Akuntansi Organisasi Nirlaba & 4 Jam \\
\hline 3 & $\begin{array}{l}\text { Standar Akuntansi } \\
\text { Pemerintahan }\end{array}$ & Jam \\
\hline 4 & $\begin{array}{l}\text { Sistem Akuntansi Pemerintah } \\
\text { Pusat }\end{array}$ & 4 Jam \\
\hline 5 & Akuntansi Pemerintah Pusat & 4 Jam \\
\hline 6 & $\begin{array}{l}\text { Sistem Akuntansi Keuangan } \\
\text { Daerah }\end{array}$ & 4 Jam \\
\hline 7 & Akuntansi BUD/PPKD & 4 Jam \\
\hline 8 & Akuntansi SKPD/OPD & 4 Jam \\
\hline & JUMLAH & 32 Jam \\
\hline
\end{tabular}

Masing peserta Pelatihan mendapat fasilitas Modul Akuntansi Sektor Publik dan Sertifikat Pelatihan yang ditanda tangani oleh Pimpinan Politeknik Negeri Malang. Hasil pelaksanaan kegiatan ini adalah tersampaikannya materi ASP yang ter-update, sehingga peserta pelatihan mempunyai bekal dan pemahaman terkait bidang Akuntansi Sektor Publik yang baik. Manfaat langsung dari pelatihan ini, peserta mempunyai teknik atau metode dalam penyampaian materi ASP di kelas karena mata pelajaran ini merupakan mata pelajaran baru di level SMK dan mempunyai bobot yang berat karena karakteristiknya berbeda dengan Akuntansi Sektor Privat.

Luaran yang dicapai dalam kegiatan PkM ini, adalah: (1) Guru-guru mampu mengevaluasi kurikulum ASP untuk siswa SMK, sehingga menghasilkan kurikulum mata pelajaran ASP utamanya bidang Akuntansi Keuangan Daerah yang sesuai dengan PP No. 71/2010 \& Permendagri 64/2013. (2) Hasil Evaluasi Kurikulum secara umum tersebut, sebagai berikut:

\begin{tabular}{|c|c|c|}
\hline No. & $\begin{array}{l}\text { Kurikulum/ } \\
\text { Silabus Lama }\end{array}$ & $\begin{array}{c}\text { Usulan Kurikulum/ } \\
\text { Silabus Baru }\end{array}$ \\
\hline 1. & $\begin{array}{l}\text { Pengantar } \\
\text { Akuntansi } \\
\text { Pemerintah Daerah }\end{array}$ & $\begin{array}{l}\text { Pengantar Akuntansi } \\
\text { Publik }\end{array}$ \\
\hline 2. & $\begin{array}{l}\text { Persamaan Dasar } \\
\text { Akuntansi Daerah }\end{array}$ & $\begin{array}{l}\text { Pengelolaan } \\
\text { Keuangan Daerah }\end{array}$ \\
\hline 3. & $\begin{array}{l}\text { Siklus Akuntansi } \\
\text { Keuangan Daerah }\end{array}$ & $\begin{array}{l}\text { Sistem Informasi } \\
\text { Keuangan } \\
\text { (SKPD \& SKPKD) }\end{array}$ \\
\hline 4. & Penjurnalan & $\begin{array}{l}\text { Perlakuan Akuntansi } \\
\text { Pendapatan, Belanja, } \\
\text { Pembiayaan, Aset, } \\
\text { Kewajiban, } \\
\text { Ekuitas }\end{array}$ \\
\hline 5. & Posting & $\begin{array}{l}\text { Siklus Akuntansi } \\
\text { Keuangan Daerah }\end{array}$ \\
\hline 6. & Neraca Saldo & $\begin{array}{ll}\text { Proses } & \text { Akuntansi } \\
\text { SKPD } & \end{array}$ \\
\hline 7. & $\begin{array}{l}\text { Penyusunan } \\
\text { Laporan Keuangan } \\
\text { Daerah }\end{array}$ & $\begin{array}{ll}\text { Proses } & \text { Akuntansi } \\
\text { SKPKD } & \end{array}$ \\
\hline 8. & & $\begin{array}{l}\text { Akuntansi } \\
\text { Konsolidasian SKPD } \\
\text { \& SKPKD }\end{array}$ \\
\hline 9. & & $\begin{array}{l}\text { Penyusunan Laporan } \\
\text { Keuangan Daerah }\end{array}$ \\
\hline
\end{tabular}




\section{SIMPULAN DAN SARAN}

Kegiatan PkM ini dilaksanakan mulai tanggal 12-15 September 2019 (32 Jam Pel), bertempat di Ruang Multimedia SMKN 1 Lumajang, diikuti 31 Peserta. Hasil dari kegiatan ini adalah: (1) Peserta mendapatkan materi yang ter-update terkait perkembangan Akuntansi Sektor Publik. (2) Peserta dapat mengevaluasi kurikulum mata pelajaran ASP sehingga menghasilkan usulan kurikulum mata pelajaran ASP yang baru, sehingga siswa tidak terbebani dengan tambahan mata pelajaran ASP, yang merupakan mata pelajaran baru dan mempunyai karakteristik yang berbeda dengan ASP. Berdasarkan hasil diskusi dengan peserta pelatihan, perlu dipertimbangkan lagi materi mata pelajaran ASP yang fokus kepada Akuntansi Keuangan Daerah, dimana untuk level SMK sangat berat karena mempunyai karakteristik yang sangat berbeda dengan Akuntansi Sektor Privat. Tim PkM menyarankan atau merekomendasikan mata pelajaran ASP lebih baik difokuskan Akuntansi untuk Desa atau Organisasi Nirlaba karena lebih sederhana dan memberi manfaat langsung kepada siswa utamanya ketika melakukan on the job training.

\section{DAFTAR PUSTAKA}

[1]. Bastian, I. (2001): Akuntansi sektor publik Indonesia. Pusat Pengembangan Akuntansi, Fakultas Ekonomi Universitas Gadjah Mada, Yogyakarta.

[2]. Burrowes, A. (2011): Accountability in Public Sector. Chartered Accountants Journal, Vol. 90, No. 1, pp. 46-47.

[3]. Guthrie, J. (1998): Application of accrual accounting in the Australian public sectorRhetoric or reality? Financial Accountability and Management, Vol. 14, No. 1, pp.1- 19.

[4]. Ivbi, Martin. (1985): The GASB: a fresh look at governmental accounting and financial reporting. Journal of Accounting, Auditing and Finance, Vol. 8, No. 4, pp. $253-268$.

[5]. Komite Standar Akuntansi Pemerintahan (KSAP). (2010): Standar Akuntansi Pemerintahan. Jakarta.

[6]. Mardiasmo. (2002): Elaborasi reformasi akuntansi sektor publik: telaah kritis terhadap upaya aktualisasi kebutuhan system akuntansi keuangan pemerintah daerah. Jurnal Akunting dan Auditing, Vol. 6, No. 1, pp. 63-82.

[7]. Mardiasmo. (2004): Akuntansi Sektor Publik, Andi offset, Yogyakarta.

[8]. Nordiawan, D. (2006): Akuntansi Sektor Publik. Edisi 2. Jakarta. Penerbit Salemba Empat.

[9]. Osbourne, D. \& Gaebler, T. (1992): Reinventing Government, Plume, New York.

[10]. Republik Indonesia. Peraturan Pemerintah no. 24 tahun 2005. Standar Akuntansi Pemerintahan.

[11]. Peraturan Pemerintah no. 71 tahun 2010. Standar Akuntansi Pemerintahan.
[12].Simanjuntak, B. (2010): Penerapan Akuntansi berbasis Akrual di Sektor Pemerintahan Indonesia. Kongres XI Ikatan Akuntansi Indonesia. 